\title{
THE ROLE OF SELF-REGULATION AND LIFE-OPTIMISM IN SEXUAL RISK BEHAVIOUR IN UNIVERSITY STUDENTS FROM HUNGARY LITHUANIA AND SLOVAKIA
}

\section{ROLA SAMOREGULACJI I OPTYMIZMU W PRZECIWDZIAŁANIU RYZYKOWNYM ZACHOWANIOM SEKSUALNYM WSRÓD STUDENTÓW Z WĘGIER, LITWY I SŁOWACJI}

\author{
Ondrej Kalina ${ }^{1(A, B, C, D, E, F, G)}$, Olga Orosová $^{1(A, D, F, G)}$, Vilma Kriaucioniene $^{2(A, B, F, G)}$, Andrea Lukács ${ }^{3(A, B, F, G)}$ \\ ${ }^{1}$ Department of Educational Psychology and Health Psychology, Faculty of Arts, P.J. Safarik University, Kosice, Slovakia \\ ${ }^{2}$ Health Research Institute, Faculty of Public Health, Medical Academy, Lithuanian University of Health Sciences, \\ Kaunas, Lithuania \\ ${ }^{3}$ Faculty of Health Care, University of Miskolc, Miskolc, Hungary
}

Authors' contribution Wkład autorów:

A. Study design/planning zaplanowanie badań B. Data collection/entry zebranie danych

C. Data analysis/statistics dane - analiza i statystyki D. Data interpretation interpretacja danych E. Preparation of manuscript przygotowanie artykułu F. Literature analysis/search wyszukiwanie i analiza literatury G. Funds collection zebranie funduszy
Tables: 4

Figures: 0

References: 42

Submitted: 2017 Aug 01

Accepted: 2017 Aug 31

\section{Summary}

Background. Personality factors have frequently been found to be associated with health risky behaviours although the findings are not always consistent and are rare in Central or Eastern Europe. Holding optimistic beliefs was found as a protective factor as women at the highest risk for HIV demonstrated lower self-esteem, less optimistic and fatal views concerning the future. Similarly, high levels of dispositional self-regulation among students, decreased alcohol use, alcohol-related negative consequences and sexual risk-taking. This study aims to explore and compare the associations between self-regulation, life-optimism and sexual risk behaviour in young adults from Hungary, Lithuania and Slovakia. Material and methods. Online questionnaires concerning health- related behaviour including sexual behaviour, optimism and self-regulation were distributed to first year university students in Hungary ( $\mathrm{N}=819,66 \%$ females), Lithuania ( $\mathrm{N}=928,70 \%$ females) and Slovakia $(\mathrm{N}=807$, $75 \%$ females). Multinomial logistic regression was performed in SPSS 16. Results. Selfregulation was associated with sexual risk behaviour as students with higher self-regulation were less likely to report high risk or moderate-risk sexual behaviour compared to those with lower self-regulation. Life optimism was not associated with any type of sexual risk behaviour. Conclusions. Taking into consideration our results on young adults as well as those conducted by others, we may see stability in self-regulation as a vital factor which may affect one's sexual behaviour during adolescence and young adulthood. As for intervention or prevention programmes, enhancing self-regulation result in reduction of substance use and sexual risk behaviour. However, such intervention should be done in early adolescence.

Keywords: optimism, self-control, sexual behaviour, university students, prevention

\section{Streszczenie}

Wprowadzenie. Czynniki osobowościowe często wpływają na podejmowanie ryzykownych zachowań zdrowotnych, chociaż wyniki badań nie zawsze są spójne. Jeśli chodzi o Europę Centralną lub Wschodnią, rzadko dokonywano badań nad zagadnieniem zachowań o charakterze seksualnym. Zauważano jednakże, że pozytywne podejście do życia to ważny czynnik, gdyż na przykład kobiety najbardziej narażone na HIV wykazały niższe poczucie własnej wartości i mniej optymistyczne poglądy na temat swej przyszłości. Z kolei, wysoki poziom samoregulacji dyspozycyjnej u nastolatków i studentów sprawia, że następuje spadek negatywnych zachowań, takich jak użycie alkoholu, negatywnych konsekwencji z nim związanych oraz podejmowania ryzyka seksualnego. Celem pracy jest zbadanie i porównanie korelacji między samoregulacją, optymizmem życia a ryzykownymi zachowaniami seksualnymi u młodych osób z Węgier, Litwy i Słowacji. Materiał i metody. Rozpowszechniono kwestionariusze online dotyczące zachowań związanych ze zdrowiem, w tym zachowań seksualnych, optymizmu i samoregulacji wśród studentów pierwszego roku na Węgrzech ( $\mathrm{N}=819,66 \%$ kobiet), Litwie $(\mathrm{N}=928,70 \%$ kobiet) i Słowacji ( $\mathrm{N}=807,75 \%$ kobiet). Przeprowadzono wielomianową regresję logistyczną przy użyciu SPSS 16. Wyniki. Samoregulacja wśród badanych studentów wykazuje powiązania z ryzykownymi zachowaniami seksualnymi. Studenci z wieksza samoregulacją rzadziej zgłaszali zachowanie seksualne o wysokim lub umiarkowanym ryzyku w porównaniu z osobami z niższą samoregulacją. Nie odnotowano powiązania optymizmu z jakimkolwiek rodzajem zachowań w zakresie seksualności w każdym kraju. Wnioski. Biorąc pod uwage wyniki naszych badań, a także tych prowadzonych w innych ośrodkach, możemy uznać samoregulację za czynnik stabilizujący, który może wpływać na zachowanie seksualne w okresie dojrzewania i młodości. Jeśli chodzi o programy interwencyjne lub zapobiegawcze, zwiększenie samoregulacji powinno skutecznie zmniejszyć przyjmowanie zakazanych substancji i liczbę ryzykownych zachowań seksualnych. Jednakże taka interwencja powinna być przeprowadzona we wczesnym okresie dojrzewania.

Słowa kluczowe: optymizm, samoregulacja, zachowanie seksualne, studenci, zapobieganie

Kalina O, Orosová O, Kriaucioniene V, Lukács A. The role of self-regulation and life-optimism in sexual risk behaviour in university students from Hungary, Lithuania and Slovakia. Health Problems of Civilization. 2017; 11(3): 180-189. doi: 10.5114/hpc.2017.70009.

Address for correspondence / Adres korespondencyjny: Ondrej Kalina, Department of Educational Psychology and Health Psychology, Faculty of Arts, P.J. Safarik University, Kosice, Moyzesova 7, 04011, Slovakia, e-mail: ondrej.kalina@upjs.sk, phone: +42155 2347109

Copyright: (C) 2017 Pope John Paul II State School of Higher Education in Biała Podlaska, Ondrej Kalina, Ol'ga Orosová, Vilma Kriaucioniene, Andrea Lukács. This is an Open Access journal, all articles are distributed under the terms of the Creative Commons Attribution-NonCommercial-ShareAlike 4.0 International (CC BY-NC-SA 4.0) License (http://creativecommons.org/licenses/by-nc-sa/4.0/), allowing third parties to copy and redistribute the material in any medium or format and to remix, transform, and build upon the material, provided the original work is properly cited and states its license. 


\section{Introduction}

There has been a significant public health concern regarding sexual risk behaviour in late adolescence and young adulthood, when young people start their own life without direct parental supervision [1]. This transition period between 18 and 25 years of age, which has been called 'emerging adulthood' [2], is characterized by the highest risk behaviours such as alcohol consumption, drug use or sexual risk behaviour (SRB) compared to any other life period [3-7]. Emerging adulthood allows for pursuing new, intense and risky experiences with greater freedom than in any other period of one's development, which is especially visible in the university environment, where there is no direct supervision [8].

The rates of SRB (e.g. inconsistent condom use, sex with unknown partners) during this life stage are likely to double, as the sexual behaviour of young people during this period is characterized by a steep growth in the number of new sexual partners [9], low condom use rates [10]; one night-stand relationships [11]; and by the simultaneous use of alcohol or drugs during intercourse [12].

Researchers have frequently found personality traits to be associated with health risky behaviours although the findings are not always consistent [13].

Sexual risk patterns may be influenced not only by behavioural, cognitive and attitudinal factors such as AIDS risk-behaviour knowledge, risk perception, attitudes and intentions to use condoms, and perception of selfefficacy but also by broader contextual factors such as one's assessment of self-esteem, self-regulation, optimism or fatalism toward the future, and degree of satisfaction with present life [14-16].

Optimism as a psychological construct is one of the major topics of positive psychology. According to many studies, optimism plays a key role in health behaviours. More optimistic people are able to cope better when they are exposed to burden or stress. In such situations, they are more likely to follow adaptive coping strategies that implicitly lead to higher well-being $[17,18]$ and better self-perceived quality of life $[19,20]$. In this study, the concept of dispositional optimism has been used. This denotes the extent to which people have positive, confident expectations about their own future outcomes [21]. According to this concept, the individuals who expect positive life outcomes have increased motivation towards goal achieving behaviour. On the contrary, failure expectancies decrease such motivation, which may lead to goal abandonment.

The following theoretical backgroud has been backed up research on optimism and risk behaviour whose conclusion was that optimistic beliefs may serve as a protective factor in health endangering behaviour. Women at high risk of HIV infection demonstated low self-esteem, low optimism about the future and tended to be less satisfied with life than women at low risk of HIV [14]. ' $n$ his study on adolescents, Nurmi [22] found negative correlations between optimism about the future and risky behaviours such as failure at school, delinquency, drug and alcohol consumption, early sexual activity and unprotected sexual activity. Similar studies conducted by Zimbardo $[23,24]$ showed that low risk behaviours were linked to future prospects. The importance of positive views on ones' future has also been found in studies concerning juvenile prisoners. The adolescents who were pessimistic about the future were more likely to have been involved in high-risk sexual behaviour compared to those optimistic about the future $[25,26]$. Another study that looked at gay and bisexual men showed that low levels of optimism on the future, high levels of dissatisfaction with present life, and a short duration of life - seeing one's life in terms of short rather than long temporal perspectives - were associated with constant engagement in high-risk sexual behaviour [27]. Optimism has also been considered as an important factor in consistent condom use. A study by Bryan and West [28] confirmed the impact of meditation on optimism about one's future and self-esteem in condom use intention.

In contrast to life-optimism, the concept of self-regulation has drawn much more attention in researchers especially in the context of health risky behaviour. Self-regulation can be seen as the capacity to regulate emotions, thoughts, attention, and behaviour in order to achieve some aim. It is characterized by capacities for planning and the ability to delay gratification [29]. In general, high levels of dispositional self-regulation have consistently been found to be protective against drinking and sexual risk in older adolescents and young adults [30] as self-regulatory skills developing in young adulthood [31]. With regard to older adolescents and young adults, research on self-regulation and sexual risk taking have found that higher levels of dispositional self-regulations are negatively associated with SRB [32,33]. A study by Quinnn [15] on college students has confirmed that the protective role of self-regulation regarding SRB as higher self-regulation predicted fewer instances of unprotected sex with non-monogamous partners.

Most studies on self-regulation and life-optimism have involved groups of adolescents or adults. Far fewer studies have explored these variables in a particular period of life, as is the case with emerging adulthood. The aim of the following study was to identify the correlations between self-regulation, life-optimism and sexual risk behaviour in the first year university students in Hungary, Lithuania and Slovakia. 


\section{Material and methods}

\section{Sample}

This study is based on the data collected in 2011 from several universities in three countries: four universities in Lithuania, two in Hungary and four in the Slovak Republic. The data were collected as part of wave 1 of the Student Life Cohort in Europe (SLiCE), a multinational longitudinal study of University students from several European countries [34]. The collaborating universities were selected through the personal contacts of the researchers involved in the study. The students were asked to complete self-administered online questionnaires. The strategies of respondents' recruitment differed in each country because of the structural differences in the participating countries. The universities in Lithuania and Slovakia provided the research team with email addresses of all enrolled students in their first year of study. The project was introduced to students during regular lectures and seminars. These students were directly invited to participate in the survey by email while the Hungarian students were informed through university newsletters and the student educational administration system. Student participation in all countries was voluntary and anonymous. Students were informed that by completing the questionnaire they provided their informed consent. They were also informed that they could terminate participation at any point while filling in the questionnaire. No incentives were provided. The permission to conduct the study was granted by the Ethics Committees of participating institutions. In total, the sample group included 2554 students: 819 from Hungary (mean age 21.2; SD= 4.1; 75.5\% females); 928 from Lithuania (mean age 20.0; SD=1.9; 70.6 \% females); 807 from Slovakia (mean age 19.9; SD= 1.1; 75.2 \% females). For statistical purposes, only those students' data who reported having had sexual intercourses and filled in the questionnaires concerning self-regulation and life-optimism were included. This resulted in a final research sample of 1085 students: 410 from Hungary (mean age 21.8; SD= 4.7; 77.3\% females); 288 from Lithuania (mean age 20.5; SD= 3.2; $75.3 \%$ females); 387 from Slovakia (mean age 20.0; SD=1.5; $79.8 \%$ females), which was used for further statistical analyses (Table 1). The samples were ethnically homogeneous as more than $94 \%$ of the respondents from each country claimed that particular ethnicity.

In Hungary, Lithuania and Slovakia the age of sexual consent differs and the minimum age is 14, 16 and 15 respectively. However, minimum legal drinking age in each country is the same, i.e. 18 years old.

Table 1. Demographic characteristic of the study participants

\begin{tabular}{|c|c|c|c|c|c|}
\hline \multicolumn{6}{|c|}{ Total sample $(\mathrm{N}=2554)$} \\
\hline \multicolumn{2}{|c|}{$\begin{array}{c}\text { Hungary } \\
\mathrm{n}=819 / 32.1 \%\end{array}$} & \multicolumn{2}{|c|}{$\begin{array}{c}\text { Lithuania } \\
\mathrm{n}=928 / 36.3 \%\end{array}$} & \multicolumn{2}{|c|}{$\begin{array}{c}\text { Slovakia } \\
\mathrm{n}=807 / 31.6 \% \\
\end{array}$} \\
\hline Males & Females & Males & Females & Males & Females \\
\hline $201 / 24.5$ & $618 / 75.5$ & $273 / 29.4$ & $655 / 70.6$ & $200 / 24.8$ & $607 / 75.2$ \\
\hline \multicolumn{6}{|c|}{ Study sample after selection $(\mathrm{N}=1085)$} \\
\hline \multicolumn{2}{|c|}{$\begin{array}{c}\text { Hungary } \\
\mathrm{n}=410 / 37.8 \%\end{array}$} & \multicolumn{2}{|c|}{$\begin{array}{c}\text { Lithuania } \\
\mathrm{n}=288 / 26.5 \%\end{array}$} & \multicolumn{2}{|c|}{$\begin{array}{c}\text { Slovakia } \\
\mathrm{n}=387 / 35.7 \%\end{array}$} \\
\hline 93 / 22.7 & $317 / 77.3$ & $71 / 24.7$ & $217 / 75.3$ & 78 / 20.2 & $309 / 79.8$ \\
\hline
\end{tabular}

\section{Measures}

Life-optimism in terms of outcome expectancies was measured by the revised version of the Life Orientation Test (LOT-R) [21,35] that consists of six items and four filler items. Participants were asked to indicate whether they agreed with the items on a five-point Likert scale ranging from strongly disagree (1) to strongly agree (5), where a higher score indicates higher optimism. Scheier et al. [21] showed that the LOT-R measures optimism as one dimension in an internally consistent way. A study examining Slovak older adolescents [36] showed that the LOT-R results are sufficiently stable over time ( $\mathrm{rtt}=0.77$ for three week span, $\mathrm{rtt}=0.76$ for two month span and $\mathrm{rtt}=0.68$ for three month span).The LOT-R was found to be correlated with four other instruments measuring subjective well-being, self-esteem, hope and anxiety which supports the convergent and discriminatory validity of this instrument. Cronbach's Alpha in the study was 0.80 .

Self-regulation was measured by the Short Self-Regulation Questionnaire (SSRQ) [37], which contains 31-items. It was designed to assess self-regulation capacity across the seven processes of self-regulation. Items are scored on a 1-5 scale (strongly disagree-strongly agree), where a higher score indicates higher selfregulation. Cronbach's Alpha in the study was 0.97.

The previous research on young American college students indicated that the SSRQ has a single factor that represents overall self-regulation capacity but it also revealed the possibility of two distinct factors (i.e. impulse control and goal setting) with acceptable reliability and validity [38]. 
Sexual behaviour was measured by means of three questions asking participants: (i) how many sexual partners they had had in the last 12 months (two and fewer / three or more); (ii) how often they had used condoms during the initial sexual intercourse with a new partner (always / almost always, occasionally, never); and (iii) if they had ever had sex under the influence of drugs or alcohol (yes / no). Those who reported three and more sexual partners, inconsistent condom use or sex under the influence of drugs or alcohol were reported as having sexual risky behaviour (SRB). By computing the previous three variables on sexual behaviour, a sexual risk index was constructed with three categories, which reflected the severity of sexual risk behaviour. The students with no sexual risk behaviour were reported as a 'sexual low risk group'. Students with one type of sexual risk behaviour were reported as the 'sexual moderate risk group' and those with two or more types of sexual risk behaviour were reported as the 'sexual high-risk group'.

\section{Statistical analyses}

Only those respondents' date who reported having had sexual intercourse and had filled in the questionnaires concerning life-optimism and self-regulation were included in the analyses. Further, their current sexual risk behaviours and levels of self-regulation and life-optimism were assessed. The differences in types of sexual risk behaviour, self-regulation and life-optimism for a particular country were tested using the chi-squared test, T-test and two way ANOVA. Next, a binary logistic regression was done to assess the association between selfregulation, life-optimism and the three types of sexual risk behaviour by country. Finally, a multinomial logistic regression was used to assess the correlation between self-regulation, life-optimism and sexual risk index by country. The results of the logistic regression are presented with the odds ratio (OR) and their $95 \%$ confidence interval (CI). For all analyses, IBM SPSS 20.0 statistical software was utilised.

\section{Results}

\section{Sexual risk behaviour, self-regulation and life-optimism}

Out of the three countries, Slovak students were more likely to use condoms inconsistently (females 27\%; males 38\%) during the initial sexual intercourse with a new partner than students from Hungary (females 18\%; males 22\%) or Lithuania (females 20\%; males 26\%). Similarly, students from Slovakia were more likely to have sex under the influence of drugs or alcohol (females 16\%; males 27\%) than their peers from Hungary (females $12 \%$; males 26\%) or Lithuania (females 15\%; males 24\%). Regarding a number of sexual partners (three and more) during the last 12 months, the highest rates were recorded in Slovak students (females 12\%); males 20\%), when compared to Hungarian (females 12\%; males 24\%) and Lithuanian (females 8\%; males 18.3\%) students. However, significant differences between countries were found only in inconsistent condom use (Table 2). As for the gender differences, it was discovered that males in all countries were more likely to have had 3 and more sexual partners and to have had sex under the influence of drugs or alcohol. No gender differences were found in condom use.

University students from Lithuania demonstrated significantly lower rates of self-regulation than their peers from Hungary and Slovakia. Similarly, university students from Lithuania and Slovakia showed significantly lower rates of life-optimism compared to their peers form Hungary (Table 2). No gender differences were found in self-regulation or optimism.

\section{Correlations between life-optimism, self-regulations and three types of sexual risk behaviour by country}

Out of the examined variables, only self-regulation was found to be associated with sexual risk behaviour. In Table 3 the students from all countries who reported higher levels of self-regulation were less likely to have had 3 and more sexual partners. Moreover, students from Slovakia and Hungary with higher levels of self-regulation were less likely to have engaged in sex under the influence of alcohol or drugs than their peers with lower levels of self-regulation. No significant relationships were found regarding condom use although those students with higher self-regulation reported lower levels of inconsistent condom use. These results also showed significant gender differences. Males with lower self-regulation had a higher chance of having risky behaviour than their female peers with lower self-regulation. Such gender differences were found in all countries regarding three and more sexual partners (Hungary and Lithuania) and condom use (Hungary and Slovakia). 


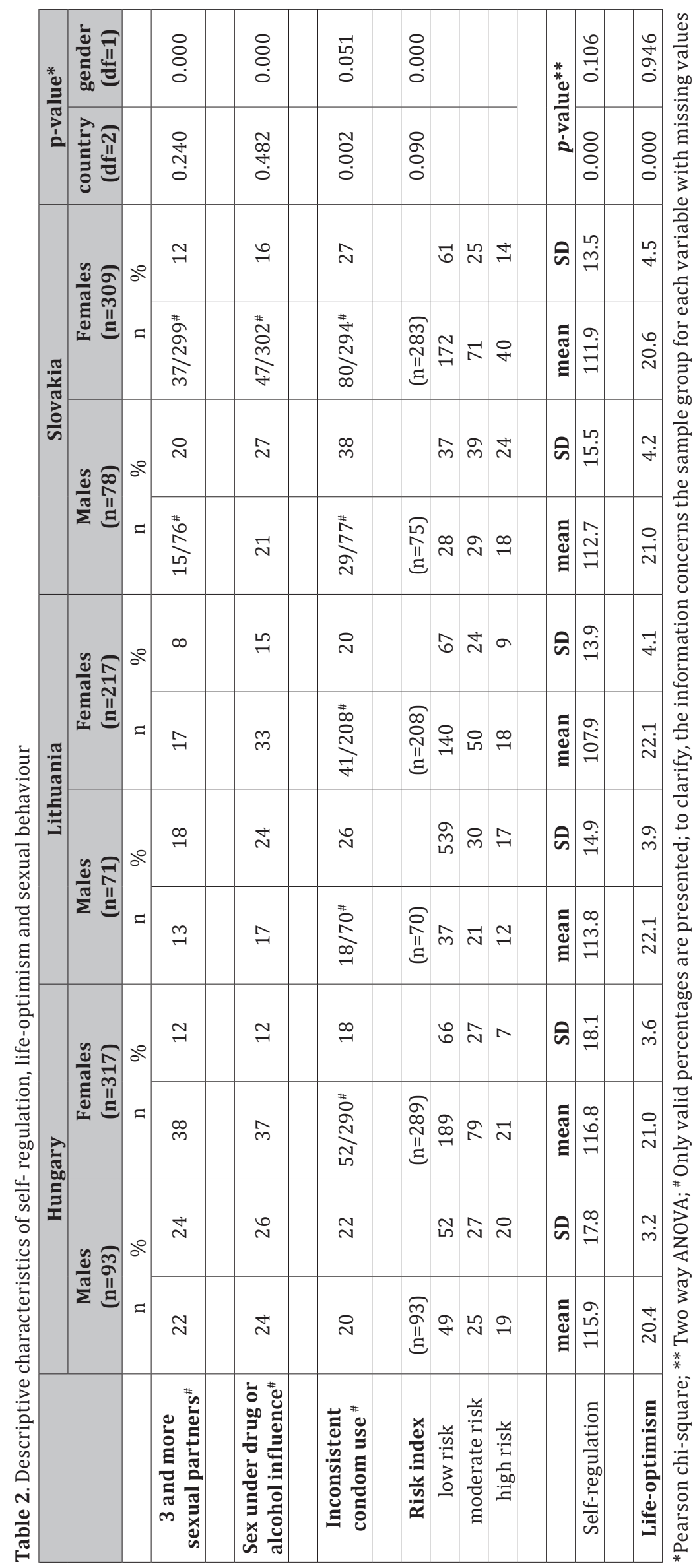


Table 3. Relationships between life-optimism, self-regulations and three types of sexual risk behaviour by country

\begin{tabular}{|c|c|c|c|c|c|c|c|c|c|}
\hline & \multicolumn{3}{|c|}{$\begin{array}{l}\text { Three and more } \\
\text { sexual partners } \\
(n=142)\end{array}$} & \multicolumn{3}{|c|}{$\begin{array}{l}\text { Having sex under drug or } \\
\text { alcohol influence } \\
(n=179)\end{array}$} & \multicolumn{3}{|c|}{$\begin{array}{l}\text { Without condom during first } \\
\text { sex with new partner } \\
(n=240)\end{array}$} \\
\hline & $\mathrm{n}$ & OR & CI (95\%) & $\mathrm{n}$ & OR & CI (95\%) & $\mathrm{n}$ & OR & CI (95\%) \\
\hline \multicolumn{10}{|c|}{ Hungary } \\
\hline Life-optimism & & 1.04 & $(0.95-1.15)$ & & 1.02 & $(0.93-1.13)$ & & 0.97 & $(0.89-1.05)$ \\
\hline Self-regulation & & 0.95 & $*(0.97-0.99)$ & & 0.97 & $* *(0.96-0.99)$ & & 1.00 & (0.98-1.01) \\
\hline Females & 38 & 1.00 & & 37 & 1.00 & & 52 & 1.00 & \\
\hline Males & 22 & 2.06 & $*(1.10-3.87)$ & 24 & 2.84 & $* *(1.50-5.40)$ & 20 & 1.11 & $(0.60-2.01)$ \\
\hline \multicolumn{10}{|c|}{ Lithuania } \\
\hline Life-optimism & & 1.05 & $(0.93-1.18)$ & & 1.00 & (0.91-1.10) & & 0.98 & $(0.89-1.07)$ \\
\hline Self-regulation & & 0.97 & $* *(0.94-0.99)$ & & 0.98 & $(0.96-1.05)$ & & 0.98 & (0.96-1.01) \\
\hline Females & 17 & 1.00 & & 33 & 1.00 & & 41 & 1.00 & \\
\hline Males & 13 & 3.54 & $* *(1.54-8.11)$ & 17 & 2.01 & $(0.97-4.14)$ & 18 & 1.90 & (0.93-3.81) \\
\hline \multicolumn{10}{|c|}{ Slovakia } \\
\hline Life-optimism & & 0.97 & $(0.90-1.04)$ & & 0.98 & $(0.92-1.05)$ & & 1.03 & $(0.97-1.09)$ \\
\hline Self-regulation & & 0.98 & $*(0.96-0.99)$ & & 0.97 & $* *(0.95-0.98)$ & & 0.97 & $(0.97-1.01)$ \\
\hline Females & 37 & 1.00 & & 47 & 1.00 & & 80 & 1.00 & \\
\hline Males & 15 & 1.60 & $(0.77-3.34)$ & 21 & 2.17 & $* *(1.15-4.18)$ & 29 & 1.50 & $(0.86-2.62)$ \\
\hline
\end{tabular}

${ }^{*} p<.05 ;{ }^{* *} p<.01$; statistically significant odds ratios $(p<.05)$ are in bold; the data are broken down by gender; OR=odds ratio

Correlations between life-optimism, self-regulations and high risk and moderate risk sexual behaviour

Table 4. presents the adjusted associations of life-optimism and self-regulation with high risk and moderate risk sexual behaviour compared to the low level of sexual behaviour as the reference category. The differences between the reference category and the high risk or moderate risk level of sexual behaviour categories were most noticeable for self-regulation. Self-regulation in students from all three countries was associated with the level of sexual risk behaviour. Students with higher self-regulation were less likely to engage in high risk or moderate sexual behaviour compared to the safe sex group. However, life-optimism was not associated with any type of sexual risk behaviour in any country. Similarly, the results showed significant gender differences

Table 4. Mutually adjusted associations of self-regulation and life optimism with high and moderate risk sex, compared to low risk sex as a reference category

\begin{tabular}{|c|c|c|c|c|c|c|c|c|}
\hline & \multicolumn{3}{|c|}{$\begin{array}{l}\text { High risk sexual } \\
\text { behaviour } \\
(n=128)\end{array}$} & \multicolumn{3}{|c|}{$\begin{array}{c}\text { Moderate risk sexual } \\
\text { behaviour } \\
(\mathrm{n}=275)\end{array}$} & \multicolumn{2}{|c|}{$\begin{array}{c}\text { Low risk sexual } \\
\text { behaviour } \\
(n=615)\end{array}$} \\
\hline & $\mathrm{n}$ & OR & $(95 \% \mathrm{CI})$ & $\mathrm{n}$ & $\mathrm{OR}$ & $(95 \% \mathrm{CI})$ & $\mathrm{n}$ & OR \\
\hline \multicolumn{9}{|c|}{ Hungary } \\
\hline Life-optimism & & 1.03 & $(0.91-1.17)$ & & 0.97 & $(0.90-1.05)$ & & 1 \\
\hline Self-regulation & & 0.97 & $*(0.93-0.99)$ & & 0.98 & $(0.96-1.01)$ & & 1 \\
\hline Females & 21 & 1.00 & & 79 & 1.00 & & 189 & 1 \\
\hline Males & 19 & 3.72 & $* *(1.50-9.20)$ & 25 & 2.05 & $*(1.02-4.10)$ & 49 & 1 \\
\hline \multicolumn{9}{|c|}{ Lithuania } \\
\hline Life-optimism & & 0.96 & $(0.86-1.07)$ & & 1.06 & $(0.97-1.00)$ & & 1 \\
\hline Self-regulation & & 0.98 & $*(0.96-0.99)$ & & 0.96 & $*(0.96-0.99)$ & & 1 \\
\hline Females & 18 & 1.00 & & 50 & 1.00 & & 140 & 1 \\
\hline Males & 12 & 2.86 & $* *(1.37-6.00)$ & 21 & 1.23 & $(0.69-2.21)$ & 37 & 1 \\
\hline \multicolumn{9}{|c|}{ Slovakia } \\
\hline Life-optimism & & 1.00 & $(0.93-1.08)$ & & 1.03 & $(0.97-1.10)$ & & 1 \\
\hline Self-regulation & & 0.97 & $* *(0.95-0.99)$ & & 0.97 & $*(0.96-0.99)$ & & 1 \\
\hline Females & 40 & 1.00 & & 71 & 1.00 & 1.00 & 172 & 1 \\
\hline Males & 18 & 2.53 & $* *(1.20-5.34)$ & 29 & 2.41 & $* *(1.31-4.45)$ & 28 & 1 \\
\hline
\end{tabular}

$\mathrm{OR}=$ odds ratio; $\mathrm{CI}$, confidence interval; ${ }^{*} p<.05 ;{ }^{* *} p<.01$; statistically significant odds ratios $(p<.05)$ are in bold; the data are broken down by gender OR 
(Table 3). Males with lower self-regulation had a higher chance of having risky behaviour than their female peers with lower self-regulation. Such gender differences were found in all countries with regard to high risk sexual behaviour and moderate risk sexual (Hungary and Slovakia).

\section{Discussion}

The main aim of this study was to explore the correlations between self-regulation, life-optimism and sexual risk behaviour in young adults. Moreover, it examined and compared sexual risk behaviour in three European countries. The proportion of sexual risk behaviour in the examined youth was similar except for the high rates of inconsistent condom use in Slovak students. The sexual risk behaviour of young adults was significantly associated with low self-regulation but not with life-optimism. With regards to the specific types of sexual risk behaviour, low self-regulation was correlated only with the number of sexual partners and having sex under the influence of alcohol or drugs. However, a higher prevalence of several types of sexual risk behaviour showed more significant relationships with self-regulation. In particular, those students with higher self-regulation were less likely to have high-risk or moderate-risk sexual behaviour compared to those with low self-regulation. Life-optimism was not associated with any type of sexual risk behaviour in any country.

\section{Role of self-regulation}

The current results on self-regulation, which is conceptualised as the ability to regulate emotions, attention and behaviour, are in line with the previous studies which have shown that low self-regulation is associated with sexual risk taking behaviour. Some studies have indicated that self-regulation is a significant longitudinal indicator of whether young people will engage in sexual risk taking [39]. Additionally, research has suggested that self-regulation shows fairly stable individual differences [40]. Thus, children who perform poorly in selfregulation may one day lack self-regulatory control and become more vulnerable to multiple forms of health endangering behaviour, including early substance use and sexual risk behaviour.

This study of individual sexual behaviours has provided a more specific picture of the role of self-regulation in sexual risk taking. Self-regulation was not associated with condom use during initial sex with a new partner in any of the three countries. On the contrary, students from all countries who reported higher levels of selfregulation were less likely to have had 3 and more sexual partners. Moreover, students from Slovakia and Hungary with higher levels of self-regulation were less likely to engage in sex under the influence of alcohol or drugs than their peers with lower levels of self-regulation. However, some studies which have explored adolescent sexual behaviour and self-regulation also found correlations in early sexual intercourse and condom. According to Raffaelli and Crockett [39], self-regulation may influence the choices that an adolescent makes after becoming sexually active (e.g., with regard to the number of partners) rather than the initiation of sexual activity per se. The difference in findings might be explained by differences in age, study design (cross-sectional, longitudinal) or by the inclusion of control variables.

Nevertheless, the results from this study which showed that poor self-regulation is associated with having sex under the influence of drugs or alcohol is consistent with the findings of Quinn and Fromme [9], who observed similar correlations. Crockett et al. [33] also demonstrated that self-regulation in middle childhood influences adolescent sexual risk behaviour in both direct and indirect ways through early adolescent substance use. This may be explained by the fact that early experimentation with substance use could serve as an early marker of a broader tendency toward problem behaviour in young adults. Therefore, this study and others concerning children and adolescents have shown that stability in self-regulation is a vital factor which may affect sexual behaviour from early adolescence to young adulthood. In terms of public health intervention or prevention programmes, enhancing self-regulation could be effective in reducing substance use and sexual risk behaviour if in place during early adolescence.

\section{Role of life-optimism}

Despite some studies showing sexual risk behaviour to be associated with low optimism [14,27], this study did not support this assumption. This could be explained by different study samples or ways of measuring optimism. Somlai et al. [14] focused only on women with a mean age of 32 years being treated for STIs, while Kalichman et al. [27] tested only homosexual and bisexual men. Other studies which have examined the role of optimism have mostly focused on patients with chronic illnesses, where optimism served as a significant contributor in the adaptation process [40]. As far as can be determined, only one study has previously explored the role of optimism in sexual behaviour in university students [41]: It examined the risk perception for developing AIDS but similarly to this study, it did not find significant differences between students with low and high optimism. 
Thus, university students with high-risk sexual behaviour did not differ in optimism compared to those with safe sexual behaviour.

\section{Strengths and limitations of the study}

This study has both strengths and limitations. One of the main strengths was that it examined the role of self-regulation and life-optimism in sexual risk behaviour in university students from three different countries. The data were gathered in three European countries in fairly large sample groups, which allowed for making an international comparison. Another strength of this study was its design, whereby the links between lifeoptimism, self-regulation and sexual risk behaviour were assessed in the university population instead of ill patients (e.g., depression, STI), as is the case with the majority of other studies.

The major limitation of this study is its cross-sectional design which limits the potential for inferences on causality. In this model, it was assumed that life-optimism and self-regulation processes preceded sexual behaviour and sexual health. This approach fails to take into account the fact that it could have been the other way around. In addition, no other sociological and psychological variables were included in the examined model, which could have provided an extensive explanation for developing certain sexual behaviours. Examining these processes and variables provides an opportunity for future studies. The study of only three types of SRB has limited the whole possible range of risky behaviour. However, inconsistent condom use with a new partner, having multiple sexual partners and having sex under the influence of drugs or alcohol should be considered as significant risk factors for this age group. Although each of these factors can be considered as an aspect of risktaking, none of them in itself is valid as an operational risk-taking behaviour. Yet, all have become important issues in health promotion.

Moreover, the external validity of these results may be restricted by the university samples. Levels of optimism and self-regulation are likely to differ between university students and their peers who did not attend courses.

\section{Implications for practice and research}

In contrast to adolescence, this period of emerging adulthood is characterized by a steep increase in health risky behaviour in all manners. As a result, individual abilities such as goal achieving behaviour, self control and self-regulation may serve as protective factors. These results have confirmed the assumption that selfregulation skills start to develop in early adolescence and may persist during young adulthood. These skills may therefore be crucial targets for interventions which often emphasise social influences such as resistance to peer pressure and enhanced communication within couples. Despite the fact that individual traits may be difficult to change, there are certain techniques such as mental contrasting with implementation intentions which may serve as a self-regulatory strategy of successful goal pursuit [42]. The data have presented a clear message that interventions should not only focus on one type of sexual risk behaviour. The concurrence of sexual risky behaviour with substance use increases the importance of interventions focused not only on one type of risky behaviour, but on the whole set of health-related behaviours. Due to the accumulation of risk behaviour in young people, focusing on prevention in a related set of unhealthy behaviours instead of a single type of unhealthy behaviour is very important. These results also bring some ideas concerning future research on some issues. Further studies could focus on the interaction between self-regulation and life optimism in the context of SRB, as no correlation with optimism was found. Moreover, studies with a longitudinal design could more accurately show how this interaction contributes to sexual risk behaviour. The analysis of other variables such as family structure, family environment or normative expectancies could also bring some new insights into the topic.

\section{Conclusion}

This study showed few differences in the SRB between students from Hungary, Lithuania and Slovakia except for a significantly greater frequency in the latter in inconsistent condom use in comparison to their Hungarian and Lithuanian counterparts. The study demonstrated that self-regulation remains an important protective factor regarding the number of sexual partners in young university students in each of the three countries. In addition, Hungarian and Slovak students who reported higher rates of self-regulation were less likely to have had sex under the influence of alcohol and drugs. These findings are a valuable addition to the literature (i) on sexual risk taking by university students and (ii) on self-regulation and its implications for individual functioning. Future directions for research have been suggested. 


\section{Disclosure and acknowledgements}

This work was supported by the Slovak Research and Development Agency under the contract No. APVV0253-11 and the Slovak Academy of Sciences under Contract No. VEGA 1/1092/12.

\section{References:}

1. Shiferaw Y, Alemu A, Assefa A, Tesfaye B, Gibermedhin E, Amare M. Perception of risk of HIV and sexual risk behaviors among University students: implication for planning interventions. BMC Res Notes. 2014 Mar 19; 7(1): 162.

2. Arnett JJ. Emerging adulthood. A theory of development from the late teens through the twenties. Am Psychol. 2000 May; 55(5): 469-80.

3. Helmer S, Mikolajczyk R, Pischke C, Zeeb H, van Hal G, Vriesacker B, et al. Personal and perceived peer use of alcohol among university and college students in seven European countries: the SNIPE study: Stefanie Helmer. Eur J Public Heal. 2013 Oct 1;23 (suppl_1): ckt126.048.

4. Pischke CR, Helmer SM, McAlaney J, Bewick BM, Vriesacker B, Van Hal G, et al. Normative misperceptions of tobacco use among university students in seven European countries: Baseline findings of the "Social Norms Intervention for the prevention of Polydrug usE" study. Addict Behav. 2015 Jul 23; 51: 158-64.

5. McAlaney J, Helmer SM, Stock C, Vriesacker B, Van Hal G, Dempsey RC, et al. Personal and Perceived Peer Use of and Attitudes Toward Alcohol Among University and College Students in Seven EU Countries: Project SNIPE. J Stud Alcohol Drugs. 2015; 76(3): 430-8.

6. Dempsey RC, McAlaney J, Helmer SM, Pischke CR, Akvardar Y, Bewick BM, et al. Normative Perceptions of Cannabis Use Among European University Students: Associations of Perceived Peer Use and Peer Attitudes With Personal Use and Attitudes. J Stud Alcohol Drugs. 2016 Sep; 77(5): 740-8.

7. Helmer SM, Mikolajczyk RT, McAlaney J, Vriesacker B, Van Hal G, Akvardar Y, et al. Illicit substance use among university students from seven European countries: a comparison of personal and perceived peer use and attitudes towards illicit substance use. Prev Med (Baltim). 2014 Oct; 67: 204-9.

8. El Ansari W, Stock C, John J, Deeny P, Phillips C, Snelgrove S, et al. Health promoting behaviours and lifestyle characteristics of students at seven universities in the UK. Cent Eur J Public Health. 2011 Dec; 19(4): 197-204.

9. Fromme K, Corbin WR, Kruse MI. Behavioral risks during the transition from high school to college. Dev Psychol. 2008 Sep; 44(5): 1497-504.

10. Douglas KA, Collins JL, Warren C, Kann L, Gold R, Clayton S, et al. Results from the 1995 National College Health Risk Behavior Survey. J Am Coll Heal. 1997 Sep; 46(2): 55-66.

11. Corbin WR, Fromme K. Alcohol use and serial monogamy as risks for sexually transmitted diseases in young adults. Heal Psychol. 2002 May; 21(3): 229-36.

12. Scott-Sheldon LAJ, Carey MP, Carey KB. Alcohol and risky sexual behavior among heavy drinking college students. AIDS Behav. 2010 Aug 22; 14(4): 845-53.

13. Vollrath M, Torgersen S. Who takes health risks? A probe into eight personality types. Pers Individ Dif. 2002 May; 32(7): 1185-97.

14. Somlai AM, Kelly JA, Heckman TG, Hackl K, Runge L, Wright C. Life optimism, substance use, and AIDSspecific attitudes associated with HIV risk behavior among disadvantaged innercity women. J Womens Heal Gender-Based Med. 2000 Dec; 9(10): 1101-11.

15. Quinn PD, Fromme K. Self-regulation as a protective factor against risky drinking and sexual behavior. Psychol Addict Behav. 2010 Sep; 24(3): 376-85.

16. Kalina O, Geckova AM, Klein D, Jarcuska P, Orosova O, van Dijk JP, et al. Psychosocial factors associated with sexual behaviour in early adolescence. Eur J Contracept Reprod Heal Care. 2011 Aug 30; 16(4): 298-306.

17. Bedi G, Brown SL. Optimism, coping style and emotional well-being in cardiac patients. Br J Health Psychol. 2005 Feb; 10(Pt 1): 57-70.

18. Burris JL, Brechting EH, Salsman J, Carlson CR. Factors associated with the psychological well-being and distress of university students. J Am Coll Health. 2010 Mar; 57(5): 536-43.

19. Mannix MM, Feldman JM, Moody K. Optimism and health-related quality of life in adolescents with cancer. Child Care Health Dev. 2009; 35(4): 482-8.

20. Wrosch C, Scheier MF. Personality and quality of life: The importance of optimism and goal adjustment. In: Quality of Life Research. 2003. p. 59-72.

21. Scheier MF, Carver CS, Bridges MW. Distinguishing optimism from neuroticism (and trait anxiety, selfmastery, and self-esteem): a reevaluation of the Life Orientation Test. J Pers Soc Psychol. 1994 Dec; 67(6): 1063-78. 
22. Nurmi JE. How do adolescents see their future? A review of the development of future orientation and planning. Developmental Review. 1991; 11(1): 1-59.

23. Zimbardo PG, Boyd JN. Putting time in perspective: A valid, reliable individual-differences metric. In: Time Perspective Theory; Review, Research and Application: Essays in Honor of Philip G Zimbardo. Cham: Springer International Publishing; 2015. p. 17-55.

24. Zimbardo PG, Keough KA, Boyd JN. Present time perspective as a predictor of risky driving. Pers Individ Dif. 1997 Dec; 23(6): 1007-23.

25. Canterbury RJ, McGarvey EL, Sheldon-Keller AE, Waite D, Reams P, Koopman C. Prevalence of HIV-related risk behaviors and STDs among incarcerated adolescents. J Adolesc Heal. 1995 Sep; 17(3): 173-7.

26. Morris RE, Baker CJ, Valentine M, Pennisi AJ. Variations in HIV risk behaviors of incarcerated juveniles during a four-year period: 1989-1992. J Adolesc Heal. 1998; 23(1): 39-48.

27. Kalichman SC, Kelly JA, Morgan M, Rompa D. Fatalism, current life satisfaction, and risk for HIV infection among gay and bisexual men. J Consult Clin Psychol. 1997 Aug; 65(4): 542-6.

28. Bryan A, Aiken LS, West SG. HIV/STD risk among incarcerated adolescents: Optimism about the future and self-esteem as predictors of condom use self-efficacy. J Appl Soc Psychol. 2004 May; 34(5): 912-36.

29. Hofmann W, Friese M, Strack F. Impulse and Self-Control From a Dual-Systems Perspective. Perspect Psychol Sci. 2009 Mar; 4(2): 162-76.

30. Wiederman MW. Self-control and sexual behavior. In: Baumeister R, Vohs K, editors. Handbook of selfregulation: Research, theory, and applications. New York: Guilford Press; 2004. p. 525-536.

31. Steinberg L, Graham S, O’Brien L, Woolard J, Cauffman E, Banich M. Age differences in future orientation and delay discounting. Child Dev. 2009 Jan; 80(1): 28-44.

32. Gailliot MT, Baumeister RF. Self-regulation and sexual restraint: Dispositionally and temporarily poor selfregulatory abilities contribute to failures at restraining sexual behavior. Personal Soc Psychol Bull. 2007 Feb 2; 33(2): 173-86.

33. Crockett LJ, Raffaelli M, Shen YL. Linking self-regulation and risk proneness to risky sexual behavior: Pathways through peer pressure and early substance use. Journal of Research on Adolescence. 2006; 4(16): 503-25.

34. Helmer SM, Sebena R, McAlaney J, Petkeviciene J, Salonna F, Lukács A, et al. Perception of High Alcohol Use of Peers Is Associated With High Personal Alcohol Use in First-Year University Students in Three Central and Eastern European Countries. Subst Use Misuse. 2016; 51(9): 1224-31.

35. Schou-Bredal I, Heir T, Skogstad L, Bonsaksen T, Lerdal A, Grimholt T, et al. Population-based norms of the Life Orientation Test-Revised (LOT-R). Int J Clin Hlth Psych. 2017; 17(3): 216-224.

36. Kövérová M, Ferjencík J. Adaptácia a orientacné overovanie psychometrických charakteristík testu zivotnej orientácie LOT-R/Slovak adaptation of Life Orientation test (LOT-R): psychometric characteristics. Cesk Psychol. 2013; 57(5): 461-73.

37. Carey KB, Neal DJ, Collins SE. A psychometric analysis of the self-regulation questionnaire. Addict Behav. 2004 Feb; 29(2): 253-60.

38. Neal DJ, Carey KB. A follow-up psychometric analysis of the self-regulation questionnaire. Psychol Addict Behav. 2005 Dec; 19(4): 414-22.

39. Raffaelli M, Crockett LJ. Sexual Risk Taking in Adolescence: The Role of Self-Regulation and Attraction to Risk. Dev Psychol. 2003 Nov; 39(6): 1036-46.

40. Murphy BC, Eisenberg N, Fabes RA, Shepard S, Guthrie IK. Consistency and change in children's emotionality and regulation: A longitudinal study. Merrill-Palmer Quarterly-Journal Dev Psychol. 1999; 45(3): 413-44.

41. Fournier M, De Ridder D, Bensing J. Optimism and adaptation to chronic disease: The role of optimism in relation to self-care options of type I diabetes mellitus, rheumatoid arthritis and multiple sclerosis. Br J Health Psychol. 2002 Nov; 7(4): 409-32.

42. Duckworth AL, Grant H, Loew B, Oettingen G, Gollwitzer PM. Self-regulation strategies improve selfdiscipline in adolescents: benefits of mental contrasting and implementation intentions. Educ Psychol. 2011 Jan; 31(1): 17-26. 